\title{
Review of sero-prevalence of human cytomegalovirus in Iraq
}

\author{
Keywords: cytomegalovirus, betaherpesvirinae, herpesviridae
}

\section{Introduction}

Cytomegalovirus (CMV) is the prototype member of Betaherpesvirinae in the subfamily Herpesviridae. ${ }^{1} \mathrm{CMV}$ is endemic in most areas of the world. The sero-prevalence of HCMV varies in different geographical areas and it ranges from $30-100 \% .^{2}$ The infection of this virus is acquired either in the perinatal period and infancy or in adulthood through sexual contact, organ transplantation or blood transfusion. ${ }^{3} \mathrm{HCMV}$, like other herpesviruses, gives lasting settlement of the organism and its reservoir are mainly monocytes and polymorphonuclear leukocytes, where the virus is shed, many years after the initial infection (present in the throat and urine). The result of infection is seen basically in larger cells, and the presence of characteristic intracellular inclusions surrounded by halo of low reflection, gives the appearance of the so-called 'Owl-eyes'. The virus gets into the salivary gland, breast epithelium, prostate, endometrium, kidney tubules, and other organs, such as bone marrow and lungs. Therefore, it can be isolated from saliva, tears, breast milk, semen, cervical secretions, blood products and urine. HCMV infection may be either latent (non-productive), lytic (productive), asymptomatic or symptomatic. $^{4}$

\section{History of CMV}

Intranuclear inclusionsof cytomegalovirus infections were first noticed in 1881 by Ribbert ${ }^{5}$ who thought they represented protozoa, He saw large cells in sections of the kidney of a luetic stillborn and in the parotid gland of children. ${ }^{5}$ In 1907 Lòwenstein ${ }^{6}$ found such cells in the parotid glands of 4 out of 30 infants. These appear to be the first descriptions of typical cytomegalic cells with intranuclear inclusions. ${ }^{6}$ In 1950 Wyatt et al. ${ }^{7}$ suggested the name, "generalized cytomegalic inclusion disease (CID)", although its viral etiology was not yet known. ${ }^{7}$ In 1953 Minder $^{8}$ first observed the virus through electron microscopy $199 \mathrm{~nm}$ particles, in the clear halo around the intranuclear inclusion of pancreatic cells in a case of CID. ${ }^{8}$ In 1970 Weller ${ }^{9}$ named the virus as "cytomegalovirus". 9

\section{Epidemiology}

Cytomegalovirus is endemic in most areas of the world. The seroprevalence of HCMV varies in different geographical areasranging from $30-100 \% .^{2}$ Seroprevalence is higher in lower socioeconomic groups, in females, and in older individuals. ${ }^{10}$ Infection comes from close contact with infectious individuals. Transmission can be vertical (transplacental from mother to fetus) or horizontal (through sexual intercourse or contact with fluids, such as saliva, urine, maternal genital secretions, breast milk, or blood). It is also transmissible through stem cells transplantation or solid organ transplantation. ${ }^{3}$

\section{CMV structure and life cycle}

CMV resembles the herpes virus virion structure and the replication cycle comprises of fully controlled cascade of gene
Review Article

Volume 6 Issue 2 - 2018

\author{
Hussam Hussain Lazim,' Haider Sabah \\ Kadhim $^{2}$ \\ 'Department of Microbiology,Al-Nahrain University, Iraq \\ ${ }^{2} \mathrm{Head}$ of Medical Microbiology Department,Al-Nahrain \\ University, Iraq
}

Correspondence: Haider Sabah Kadhim, MBChB, MSc, PhD Medical Microbiology, Head of Medical Microbiology Department, College of Medicine- Al-Nahrain University, AlKadhimiya P.O. Box 70056 Baghdad, Iraq, Email hskadhim@colmed-alnahrain.edu.iq

Received: December 05, 2017 | Published: March 02, 2018

capable of expression. ${ }^{1}$ The virion has an icosahedral protein capsid that contains the double-stranded DNA. The capsid is surrounded by a proteinaceous tegument and an outer lipid envelope. ${ }^{1}$ Virions acquire entry into a cell through a membrane fusion event including the outer membrane of the cell and glycoproteins on the lipid envelope of virions. Following the fusion of these two membranes, the DNAcontaining protein capsid and the tegument proteins are released into the cell. ${ }^{11}$ The gene expression pattern follows a similar cascade used by other herpes viruses. ${ }^{12}$ During the lytic infection, viral immediateearly genes are expressed. ${ }^{13}$ The expression of these genes results in the production of viral immediate-early proteins that modulate the host cell environment and stimulate the expression of viral early genes. ${ }^{1}$ The viral-immediate early genes produce proteins that are responsible for replicating the double-stranded viral genomic DNA. After the DNA replication, these immediate-early genes turn on the expression of viral late genes. The viral late proteins are mainly structural components of the virion that help in the assembly and exit of newly formed viral particles. ${ }^{1}$ Immediate-early genes in HCMV can be silenced in certain cell types upon infection resulting in latent infection. ${ }^{14} \mathrm{~A}$ latent infection is characterized by the minimization of viral gene expression and the inhibition of the assembly and exit of new viral progeny. ${ }^{11}$ However, latent infections can turn out into lytic infection in response to certain environmental signals, which causes disease and favors the multiplication of the virus. ${ }^{1,12}$

\section{CMV pathogenicity}

Research to validate the correlation of CMV infection with age denoted the presence of three periods of increased incidence of infections: early childhood, adolescence and the reproductive period. The virus can be present in different secretions of an infected person, such as discharge from the oropharynx, urine, vagina, semen, milk, and blood components. The virus spreads by direct contact with an infected person, vertically from mother to fetus, and parenteral, i.e. blood transfusions, organ or bone marrow transplants. ${ }^{15}$ 
Immunosuppression is a major risk factor for the development of severe primary infection. In this group of patients, the previous risk of cytomegalovirus pneumonia was $10-30 \%$, roughly leading to $80 \%$ of mortality. In the recent past several findings reveal a decrease in these numbers due to the use of prophylactic and/or therapeutic antiviral drugs to reduce the frequency of reactivation. ${ }^{16} \mathrm{CMV}$ can infect remarkably wide range of cells within its host. The virus is also capable of infecting parenchymal cells and connective tissue cells of any organ and various hematopoietic cell types. Epithelial cells, endothelial cells, fibroblasts and smooth muscle cells are the predominant targets for virus replication. ${ }^{17}$ The primary pathway of infection is the respiratory route or through sexual coition.

CMV, like other herpesviruses, can survive for longer periods and its reservoir are monocytes and polymorphonuclear leukocytes, where the virus is shed, after many years of initial infection (present in the throat and urine). The result of infection is seen basically in larger cells, and the presence of characteristic intracellular inclusions surrounded by halo of low reflection, gives the appearance of the so-called 'Owl-eyes'. The virus gets into the salivary gland, breast epithelium, prostate, endometrium, kidney tubules, and other organs, such as bone marrow and lungs. Therefore, it can be isolated from saliva, tears, breast milk, semen, cervical secretions, blood products and urine. ${ }^{15} \mathrm{CMV}$ infection may be either latent (non-productive), lytic (productive), asymptomatic or symptomatic. Clinical manifestations of CMV infection in immunocompromised patients include: prolonged fever over $38^{\circ} \mathrm{C}$ with (or without) leukopenia, hepatitis, pancreatitis, gastrointestinal disorders, pain with fever, inflammation of the oesophagus, dysphagia, disorders that may be associated with Candida infection, interstitial pneumonia, inflammation of the heart muscle, bladder inflammation, inflammation of the retina -frequently observed in AIDS patients..$^{18}$

\section{Diagnosis and treatment}

The diagnosis of CMV infection can be confirmed by one of the following: electron microscopic detection of typical CMV virion, histologic or cytologic detection of typical CMV cytopathology, isolation of virus, detection of CMV antigen in blood and tissues, detection of CMV genome in tissues, DNA amplification and serology. ${ }^{19}$ The systemic drugs approved for CMV treatment are ganciclovir, or its prodrug valganciclovir, foscarnet, and cidofovir. ${ }^{20}$

\section{CMV in Iraq}

The analysis was based on the collection and summarization of 46 Iraqi articles. These articles have been collected from the Iraq academic scientific journals website (www.iasj.net) and from GoogleScholar. The majority of these studies focused on the association between the pregnant and aborted women with CMV infection followed by studies on patients with tumors and CMV and there were other studies with different relationships to the virus.

\section{Studies about CMV on pregnant and aborted women}

There were several studies in different parts of Iraq, especially in Baghdad. One of cases reported by Al-Baiati et al. ${ }^{21}$ included 152 aborted women and $15(10 \%)$ were positive for CMV IgM and 129 (85\%) were positive for CMV IgG. ${ }^{21}$ Majeed $^{22}$ in 2011 reported a study involving 270 women of 20-35 years. The result revealed 90 cases positive for $\mathrm{CMV}$, of which 62 cases were positive for CMV IgM and 28 cases were positive for CMV IgG. ${ }^{22}$ Another study reported by Hussan $^{23}$ in 2013 revealed 44 positive cases for CMV IgM out of 210 women with history of one or more unexplained abortion. ${ }^{23} \mathrm{Ahmed}^{24}$ in 2013 reported a study performed on 214 aborted women. CMV specific IgG and IgM antibody was detected in 151(70.5\%) of the 214 abortion case.

The subjects included in the study were divided in two age groups based on over 25 and less than 25 years of age ( $\leq 25$ (56 cases ( $37 \%)$ ), $>2595(63 \%)$ cases, which are more vulnerable to infection). These comprised of $142(66.36 \%)$ recurrent \& inevitable abortion, $2(0.93 \%)$ with intrauterine death, and 7(3.27\%) with abnormal child. ${ }^{24}$ Another study performed in 108 women with abortion was reported by Khalf et $\mathrm{al}^{25}$ in 2012. This study included three groups of patients. First group comprised of 30 women suffering from premature delivery and 5 of them were positive for IgM CMV, the second group had 35 women suffering from recurrent abortion and 5 of them were positive for IgM CMV while the third group included 43 women suffering from intra uterine death and 7 of them were positive for IgM CMV. ${ }^{25}$ Nader et al. ${ }^{26} 2012$ reported a study done on 165 pregnant women, of which 13 women were positive just for IgM CMV and 6 of them the gestation ended with abortion outcome, 30 women were positive for $\operatorname{IgM}$ and $\operatorname{IgG}$ with 6 abortion cases and 66 women were positive for IgG CMV and 17 of them had abortions while the number of abortion cases among negative women (56 cases) was 9. ${ }^{26}$ Another study was reported by Abdul mohymen et al. ${ }^{27}$ in 2009 performed in three groups of women. The first group included 63 women with recurrent spontaneous abortion and 11 cases were positive for IgM CMV and 3 cases were positive for IgG CMV. The second group comprised of 34 women with non-recurrent spontaneous abortion and 5 cases were positive for IgM CMV and all the cases negative for IgG CMV; while the third group included 23 women with successful pregnancy and the result was negative for both IgM and $\operatorname{IgG} .{ }^{27} \mathrm{Al}$-Azzawi ${ }^{28}$ reported a study on 161 pre-marital women without any clinical evidence of CMV infection. They were screened for the presence of IgG and IgM antibodies against CMV by ELISA test. The $\operatorname{IgG}$ antibodies were detected in 58 which gave prevalence rate of $36 \%$, while the $\operatorname{IgM}$ antibodies were detected in $16(9.9 \%)$. The number of both $\mathrm{IgG}$ and IgM sero positive was $50(31.1 \%){ }^{28}$

In Wasit governorate, one of the studies reported by Al-Shammary ${ }^{29}$ in 2014 included 750 aborted and pregnant women and the diagnosis was based on the CMV IgM and the result was 345(43.9\%) positive cases..$^{29}$ Another study reported by Jasim et al..$^{30}$ in 2011 in 300 aborted women, revealed the positive cases for CMV IgM 161(53.6\%) and $236(78.6 \%)$ positive for CMV IgG..$^{30}$

In the West of Iraq, Al-Anbar governorate, one of the studies performed in 87 pregnant women reported by AL-Ouqaili et al. ${ }^{31}$ in 2010 revealed $29(33.3 \%)$ positive cases for CMV IgM and 25(28.5\%) cases positive for CMV IgG. ${ }^{31}$ Another study reported by Al-Mishhadani et al. ${ }^{32}$ in 2008, in 230 aborted women and 110 pregnant women, showed $14(6.1 \%)$ cases positive for CMV IgM and 208(90.4\%) cases positive for CMV IgG of aborted women while the pregnant women $4(3.6 \%)$ cases of them were positive for CMV IgM and $91(82.7 \%)$ cases were positive for CMV IgG. ${ }^{32}$

In Babylon, the first study reported by Al-Saeed et al. ${ }^{33}$ in 2008 in 120 aborted women showed $35(79.5 \%)$ and $8(18.8 \%)$ positive cases 
for CMV IgG and IgM respectively. ${ }^{33}$ Another study performed in 180 pregnant women reported by Al-Marzoqi et al..$^{34}$ in 2012 exhibited 103(57.2\%) cases positive for CMV IgM. ${ }^{34}$ Kadum et al. ${ }^{35}$ in 2013 reported the third study in 115 aborted women. There were $75(65 \%)$ cases positive for $\mathrm{CMV}$, the diagnosis was based on serological technique (IgM and IgG). ${ }^{35}$ Ahmed et al. ${ }^{36}$ in 2014 reported a study done on 214 women with pregnancy associated problem from Baghdad and Al-Hilla. The result showed 51(33.8\%), 72(47.7\%) and $28(18.5 \%)$ cases were positive for CMV IgM, IgG and both $\operatorname{IgG}+\operatorname{IgM}$ respectively, CMV DNA load were tested in 18 cases which were seropositive to CMV (had high IgG and or IgM ELISA titer) and the results showed that the women in the age group $\geq 25$ have a higher CMV/DNA viral load than the women in less than 25 age group. ${ }^{36}$

Not far from Babylon, in Holy Kerbalaa governorate; Saad et al. ${ }^{37}$ in 2013 reported a study involving 130 women with bad obstetric history. The history of these women consisted of abortion in $116(89.23 \%)$, early neonatal death in $8(0.61 \%)$ and congenital malformation in $6(0.46 \%), 46(35.38 \%)$ cases were positive for CMV IgM..$^{37}$ In the same governorate but in Al-Hindia City, AL-Salihi et al..$^{38}$ in 2011 reported a study on 87 women had history of abortion (single or recurrent). CMV infections was detected in $15(17.2 \%)$ sera out of 87 and were positive for CMV antibodies, 3(18.5\%) cases were positive for IgM and $12(81.4 \%)$ cases positive for $\mathrm{IgG}^{38}$

Another study reported by Al-Shimmery ${ }^{39}$ in Al-Diwaniyah in 2011 in 125 aborted women revealed 22(17.6\%), 43(34.4\%) and $14(11.2 \%)$ positive cases for CMV IgM, IgG and both IgM and IgG respectively. ${ }^{39}$ Al-Muhanna et al. ${ }^{40}$ in 2014 reported a study in 428 women with abortion. These women came from three governorate of Euphrates Middle Area (Kerbalaa, Al-Najaf and Al-Diwanyia). The diagnosis was based on serological technique (CMV IgM and IgG) and the result showed 261 positive cases. ${ }^{40}$ In Thi-Qar governorate, there were three studies about this subject. Al-Khafaji et al. ${ }^{41}$ in 2010 studied 60 aborted women and the result showed 60 of 60 women (100\%) with antibodies against CMV, 9(15\%) IgM antibodies, 21(35\%) IgG antibodies and $30(50 \%)$ with both IgM and IgG. ${ }^{41}$ Another study was reported by $\mathrm{Hadi}^{42}$ in 2011 in 190 aborted females. This study was based on serological technique and the result showed 18 and 32 cases were positive for CMV IgM and IgG respectively. ${ }^{42}$ The last study was done in 400 aborted women and was reported by Al-Abady et al. ${ }^{43}$ in 2013. The result revealed 22(5.5\%), 197(49.25\%) and 7(1.75\%) cases positive for CMV IgM, IgG and IgM+IgG respectively. 50 cases positive for CMV were tested by using PCR and the result disclosed $13(26 \%)$ positive cases. ${ }^{43}$

In the north of Iraq, there were many studies about this virus. One of them in Mosul involving 100 women with high delivery risk factors reported by AL-Taie ${ }^{44}$ in 2010 disclosed that cases were included in this study based on previous history of having 2-3 pregnancy loss, intrauterine deaths, preterm deliveries and intrauterine growth retardation. From 100 cases with high delivery risk factors, abortion occur in $(38 \%)$, intrauterine growth retardation in $(32 \%)$, intrauterine death in $(13 \%)$, premature labor in $(6 \%)$, early neonatal death in $(8 \%)$, and congenital malformation in (12\%). 24(24\%) cases were positive for CMV IgM. ${ }^{44}$ Hama et al. ${ }^{45}$ in 2013 reported a study in 35 aborted women and 170 pregnant women in Sulaimania city. Among the 35 pregnant women with abortion history, only $7(20 \%)$ showed IgM positive results, while $30(85.7 \%)$ were seropositive for $\operatorname{IgG}$ and out of 170 pregnant women the result was $8(4.7 \%), 109(64.1 \%)$ cases were positive for CMV IgM, IgG respectively. ${ }^{45}$ Another study by Hassan et al. ${ }^{46}$ in 2014 in Kirkuk reported the presence of positive cases in women. This study included 547 women with bad obstetric history and 291 women with normal previous pregnancy. The result disclosed 21(38.3\%), 499(91.2\%) cases positive for CMV IgM, IgG respectively of aborted women, while in pregnant women $13(4.4 \%)$, 273(93.8\%) were positive for CMV IgM, IgG respectively. ${ }^{46}$

\section{Studies about the correlation between CMV and tumors}

There are several studies regarding the relationship between the virus and different types of tumors. The majority of these studies discussed the relationship between the CMV and adenocarcinoma. One of them was reported by Mukhlis ${ }^{47}$ in 2009 and done on 26 surgical biopsy specimens of colorectal adenocarcinoma were obtained in paraffin-blocks; the detection of CMV was obtained by in situ hybridization technique. The result was 20(76.9\%) compared to 10 normal colon tissue which revealed no hybridization signals. Inclusion bodies were detected in $11(42.3 \%)$ cases with positive hybridization signals. ${ }^{47}$ Allawi et al. ${ }^{48}$ in 2008 reported a study in 23 cases of colon adenocarcinoma and 8 cases were used as control group (margin of excision). The diagnosis of CMV was based on the presence of proteins (pp43, pp76) within epithelial cells of colorectal carcinoma by using immunohistochemistry (IHC) technique. The results of IHC test showed specific nuclear and cytoplasmic reaction in 19 from the total number 23(82.60\%), while all control group showed no reaction. ${ }^{48}$ Al-Obaidi ${ }^{49}$ in 2008 studied 32 colorectal adenocarcinomas and eight colorectal hyperplastic polyps. Tissues of normal tumor margin were considered as control. The diagnosis was based on immunohistochemistry analysis using monoclonal antibody of HCMV early protein. CMV early protein was detected in five out of $32(15.6 \%)$ colorectal adenocarcinomas, while none of the eight colorectal hyperplastic polyps and tissues of normal tumor margins was positive for the virus early protein. ${ }^{49}$ Another study was done in 60 paraffin -embedded specimens of 35 adenocarcinoma, 15 villous adenoma, and 10 normal tissues from the margins of the excision as a control.

This study was reported by AL-Mosawi ${ }^{50}$ in 2008 and this specimens were tested by IHC to detect the presence of CMV proteins, early protein and a mixture of monoclonal antibodies of early and immediate early proteins. The results of IHC assay showed specific nuclear and cytoplasmic reaction of CMV proteins within the epithelial cells of 31 colorectal adenocarcinoma $(88.5 \%)$ specimens and 8 villous adenoma (53.3\%) specimens. However, no nuclear or cytoplasmic reactions were showed in case of control..$^{50} \mathrm{Al}$-Mosawi et al. ${ }^{51}$ in 2007 reported a study in 55 paraffin-embedded specimens of 33 adenocarcinoma, 12 villous adenoma, and 10 normal tissues from the margins of the excision as a control. The diagnosis was based on the presence of CMV protein pp 65 by using IHC. The results of IHC assay showed specific nuclear and cytoplasmic reaction of HCMV proteins within the epithelial cells of colorectal adenocarcinoma $25(75.75 \%)$, and villous adenoma $10(83.33 \%)$, in addition to that no nuclear or cytoplasmic reaction were showed in any case of control group. ${ }^{51}$ Thirteen specimens of colorectal adenocarcinoma and 5 specimens of villous adenoma were tested by using PCR to detect early gene (pp65) expression within host DNA, This study was reported by AL-Mosawi 
et al. ${ }^{52}$ in 2011 and the results of PCR assay showed specific single band in 9 of 13 specimens (69.23\%) of colorectal adenocarcinoma, and 3 of $5(60 \%)$ of villous adenoma. ${ }^{52}$

Some of studies were done on glioma, there were two studies about this topic. One of them reported by Abdullah et al. ${ }^{53}$ in 2009; thirty eight (38) of glial tumor specimens were obtained in paraffin blocks compared to eight normal brain autopsy specimens and the diagnosis was done by in situ hybridization (ISH) technique. The biotinylated probe specific for mRNA encoded CMV-Matrix Protein showed hybridization with viral nucleic acids in $34(73.9 \%)$ cases of malignant glial tumor specimens. ${ }^{53}$ Shamran et al. ${ }^{54}$ in 2015 studied 50 paraffin-embedded blocks from glioma patients and benign meningioma patients. IHC were used in the diagnosis of CMV antigen expression by using m-Abs specific for HCMV proteins (IE1-72, pp65, and late antigen). Out of 36 glioma samples; 33 (91.67\%), 28 $(77.78 \%)$ and $26(72.22 \%)$ were positive for IE1-72, pp65, and late antigen, respectively. ${ }^{54}$

Ali et al..$^{55}$ in 2013 studied 70 formalin-fixed paraffin-embedded in oral tissues. 60 of them were related to patients with oral squamous cell carcinoma, and 10 blocks of individuals with apparently-healthy oral tissues. Positive in situ hybridization reactions for CMV-DNA were observed in $43.3 \%$ of the total screened tissues. Thirty three out of sixty $(55 \%)$ oral squamous cell carcinoma showed positive immunohistochemical reactions indicating P53 over-expression, and $18.3 \%$ showed presence of CD8-positive tumor infiltrating lymphocytes. None of these control groups showed positive reaction for CMV-DNA, p53, or CD8 marker. ${ }^{55}$

Six hundred forty one blood samples (291 samples from leukemic patients and 350 samples from controls) were collected and the sera were tested for the presence of IgG and IgM for CMV. This study was reported by Omer et al. ${ }^{56}$ in 2011 and the result disclosed $96.2 \%$ and $12 \%$ for patients; $91.6 \%$ and $8 \%$ for controls respectively. ${ }^{56}$ Mohammed et al. ${ }^{57}$ in 2015 carried out a study in 50 samples of cancer mass and non-neoplastic safe margin (SM) tissues of breast cancer. The samples were collected and processed for paraffin block to apply IHC and hematoxylin-eosin staining. In addition to that, 30 blood samples collected from patients and healthy women (controls) for detection of (antiCMV) IgG and IgM by ELISA. About 38 samples (76\%) of 50 samples diagnosed as invasive ductal carcinoma (IDC). The results showed that the presence of antiCMV antibody IgG in $100 \%$ of patients while the IgM presented in $76.7 \%$ of patients. The positive results of CMV protein comprise $34(89.4 \%)$ for immediate early $1(\mathrm{IE} 1)$ protein, $35(92.1 \%)$ for late protein, and $34(89.4 \%)$ for phosphoprotein 65 (pp65) from 38 samples of IDC. The results also showed the absence of expression to CMV late and pp65 proteins and low percentage $(10 \%)$ of IE1 protein in the SM tissues. ${ }^{57}$ From all these articles it may be concluded that there is a relation between the $\mathrm{CMV}$ and cancer, but the exact role of the virus and pathogenesis is unclear.

\section{Studies about CMV with other diseases}

Beginnings from the studies about the presence of the virus among blood donors, the first one reported by Yasir et al ${ }^{58}$ in 2008 and done in Najaf on 120 venous blood samples from male donors. ELISA was used to detect CMV IgG in the samples and the result was 56(46.6\%) seropositive out of 120 samples. $^{58}$ In Mosul, Al-Dabbagh $^{59}$ in 2011 reported a study in 90 blood donor samples which were randomly obtained from central blood bank of Mosul city and investigated for IgM of CMV by the serological method ELISA. The result was $10(11.11 \%)$ seropositive. ${ }^{59}$ There was a study about screening of CMV in diabetic patients. This study was done in Najaf by Yasir et al. ${ }^{60}$ in 2013 in 140 blood samples of diabetic patients. ELISA was used to detect CMV IgM and PCR was used to detect viral DNA in samples. The results showed 49(35\%) samples positive for CMV IgM and 27(19.2\%) samples were positive for PCR test..$^{60}$ In the same governorate, Yasir et al. ${ }^{61}$ in 2012 reported a study in 300 blood and seminal fluid of infertile male. The blood samples were tested by ELISA to detect CMV IgG and IgM while the seminal fluid samples were tested by PCR to detect viral DNA. The results revealed $31(11 \%)$ samples positive for IgM and 234(78\%) samples were positive for IgG. The PCR technique disclosed $22(7.4 \%)$ positive confirmations out of 300 samples. ${ }^{61}$

There were also studies about the association between CMV infections with periodontitis. One of reports by Al-Alousi ${ }^{62}$ in 2013 included 35 periodontitis patients and 18 healthy controls. Saliva samples were tested for CMV IgG by ELISA and the result showed that the frequency of CMV in chronic periodontitis patients was significantly higher when compared to healthy control group. ${ }^{62}$ Another study was reported by Abid Aun et al. ${ }^{63}$ in 2014 in 53 chronic periodontitis patients. This study aimed to detect CMV DNA in saliva by using real time - PCR, the result showed $12(22.6 \%)$ positive patients. ${ }^{63}$ There was a study about thalassemic patients and CMV in 104 blood samples for diagnosing CMV IgM. Twenty five (24\%) samples were positive. ${ }^{64}$

The fulminant hepatic failure (FHF) patients were also involved in the studies on CMV. Al-Azzawi et al.$^{65}$ in 2013 reported a study in 31 patients with FHF. Just 2(6.5\%) had CMV. ${ }^{65}$ The last study was reported by Khudir et al. ${ }^{66}$ in 2014 in 186 healthy students at Diyala University. The diagnosis was based on the detection of CMV IgM and IgG. A total of 181(97.4\%) students were seropositive for CMV IgG; out of those, 95(51.2\%) were male students and 86 (46.2\%) were female students. In addition, $3(2$ females and 1 male) students (1.6\%) were CMV IgM seropositive. ${ }^{66}$ Based on these above studies it can be concluded that CMV has significant role in aborted women and other congenital problem. Moreover, $\mathrm{CMV}$ has wide distribution in different areas of Iraq.

\section{Acknowledgements}

None.

\section{Conflict of interest}

The author declare that there is no conflict of interest.

\section{References}

1. Mocarski ES, Shenk T, Pass RF. Cytomegaloviruses. In: Knipe DM, Howley PM, editors. Fields virology. 5th ed. Philadelphia: Lippincott Williams; 2007. p. 2701-2772.

2. Crough T, Khanna R. Immunobiology of human cytomegalovirus: from bench to beside. Clin microbiol Rev. 2009;22(1):76-98.

3. Badami KG. CMV and transfusions, an old story that's not quite over yet. International Journal of Clinical Transfusion Medicine. 2014;2:7-19.

4. Powers C, De Filippis V, Malouli D, et al. Cytomegalovirus immune evasion. Current Topics in Microbiology and Immunology. 2008;325:333359. 
5. Ribbert H. Ueberprotozoenartige Zellen in der Niereeinessyphilitischen neugeborenen und in der parotis von kindern. Zbl All Pathol. 1904;15:945-948.

6. Lòwenstein C. Ueberprotozoenartige gebilde in den organen von kindern. Zbl All Pathol. 1907;18:513-718.

7. Wyatt JP, Saxton J, Lee RS, et al. Generalized cytomegalic inclusion disease. J Pediatr. 1950;36(3):271-294.

8. Minder WH. Die Aetiologie der cytomegaliainfantum. SchweizerischemedizinischeWochenschrift. 1953;83:1180-1182.

9. Weller TH. Cytomegalovirus: the diYcult years. The journal of infectious diseases. 1970;122(6):532-539.

10. Bate SL, Dollar SC, Cannon MJ. Cytomegalovirus seroprevalence in the United States:the national health and nutrition examination surveys, 1988-2004. Clin Infect Dis. 2010;50:1439-1447.

11. BroKs GF, Carroll KC, Butel JS, et al. Herpeviruses. In: BroKs GF, Carroll KC, Butel JS, et al. editors. Jawetz, Melnick and Alberdigś medical microbioloy. 24th ed. New York: Mc Graw Hill; 2007. p. 428-450.

12. Kalejta RF. Tegument proteins of human cytomegalovirus. Microbiol Mol Biol Rev. 2008;72(2):249-265.

13. Saffert RT, Penkert RR, Kalejta RF. Cellular and viral control over the initial events of human cytomegalovirus experimental latency in CD34+ cells. J Virol. 2010;84(11):5594-5604.

14. Biron KK. Antiviral drugs for cytomegalovirus disease. Antiviral research. 2006;71(2-3):154-163.

15. Po lz- Dacewicz M, Fołtyn S, Macieląg P, et al. Cytomegalovirus (CMV) - a new prospect for Prevention. Journal of Pre - Clinical and Clinical Research. 2013;7(2):118-123.

16. Durlik M. Zakażeniewirusemcytomegalii u biorcówprzeszczepównarządowych. Nefrologiai Dializoterapia Polska. 2009;13(3):157-163.

17. SinzgerC, Digel M, Jahn G. Cytomegalovirus cell tropism. Curr Top Microbiol Immunol. 2008;325:63-83.

18. Boeckh M, Geballe AP. Cytomegalovirus: pathogen, paradigm, and puzzle. The Journal of Clinical Investigation. 2011;121(5):1673-1680.

19. Jahan M. Laboratory Diagnosis of CMV Infection: A Review. Bangladesh J Med Microbiol. 2010;4(2):39-44

20. Biron KK. Antiviral drugs for cytomegalovirus diseases. Antiviral Research. 2006;71(2-3):154-163.

21. Al-Baiati HAM, Muhsin MA, Jabbarb RN. Seroprevalence of Human CytomegaloVirus (HCMV) in aborted women in Baghdad province. International Journal of Current Microbiology and Applied Sciences. 2014;3(2):97-102.

22. Majeed AKh. Toxoplasmagondii and cytomegalovirus seropositivity pathogens in high- risk patients in Iraq. Al-Anbar J Vet Sci. 2011;4(1):4149 .

23. Hussan BM. Study the Prevalence of ACL, APL, CMV, HSV, Rubella and toxoplasma gondii in aborted women in baghdad. Medical Journal of Babylon. 2013;10(2):455-464.

24. Ahmed ZK. Seroprevalence of Cytomegalovirus (CMV) in women with pregnancy associated problem. Journal of Babylon university. 2013;21(6):2104-2107.

25. Khalf MS, Ahmad DW, Ibraheem KA. The Seroprevalence of IgM among Iraqi aborted women infected with human Cytomegalovirus. The Iraqi Post Graduate Medical Journal. 2012;11(1):123-129.

26. Nader S, Ayad M. Cytomegalovirus seroprevelance in Iraqi pregnan women. The Iraqi Postgraduate Medical Journal. 2012;11(3):303-307.
27. Abdul Mohymen N, Hussien A, Hassan FK. Association between TORCH agents and recurrent spontaneous abortion. Iraqi J Med Sci. 2009;7(4):40-46.

28. Al-Azzawi RHM. Seroprevalence of cytomegalovirus infection in pre-marital women in some Baghdad hospitals. Iraqi Journal of Science. 2012;53(1):40-45.

29. Al-shammary RN. Prevalence of Cytomegalovirus among pregnant women relation to congenital abnormalities in embryos and children in Wasit province. Journal of Kerbala University. 2014;12(1):86-91.

30. Jasim M, Majeed HA, Ali AI. Performance of serological diagnosis of TORCH agents in aborted versus non aborted women of Waset province in Iraq. Tikrit Medical Journal. 2011;17(2):141-147.

31. AL-Ouqaili MT, AL-Karboli AY. Immunological Study of Cytomegalovirus Infection in women with recurrent fetal loss in Ramadi City, West of Iraq. Al-Anbar Medical Journal. 2010;8(1):74-78.

32. Al-Mishhadani JI, Al-Janabi AU. Toxoplasmosis and Cytomegalovirus infection among aborted women in Al-Anbar Governorate. Al-Anbar Medical Journal. 2008;6(1):88-97.

33. Al-Saeed MS, Muhsin MA, AL-Juburi GJ. Study the role of toxoplasma gondii, cytomegalovirus and anti-phospholipids antibodies in cases of abortion among women in Hilla city. Al-Qadisiah Medical Journal. 2008;4(6):27-34

34. Al-Marzoqi AHM, Kadhim RA, Al-Janabi DKF. Seroprevalence study of IgG and IgM antibodies to toxoplasma, rubella, cytomegalovirus, chlamydia trachomatis and herpes simplex ii in pregnancy women in Babylon province. Journal of Biology, Agriculture and Healthcare. 2012;2(10):159-164.

35. Kadum SA, Abbas AF. A study of some immunological features in aborted women infected with Toxoplasma gondii and Cytomegalovirus in Hilla city. Journal of Al-Qadisiyahfor Pure Science. 2013;18:17-30.

36. Ahmed ZK, Ahmed ZK, Salman ZQ. Quantitative Detection of Human Cytomegalovirus (HCMV) Gene in Iraqi Women with Pregnancy Associated Problems. Iraqi Journal of Biotechnology. 2014;13(1):30-38.

37. Saad A, Hussein BW, Rahi SJ. Serological Study for TORCH Infections by ELISA Method in Women with Bad Obstetric History in Kerbala City. KerbalaJorunal of Medicine. 2013;6(2):1621-1624.

38. AL-Salihi NJ, AL-Aaraji SM. A Study of the Some Causes Associated with Single and Recurrent Spontaneous Abortion in Al-Hindia City. Medical Journal of Babylon. 2011;8(4):497-506.

39. Al-Shimmery MN,Al-Hilaly HA, AI-khafaji AA. Seroprevalence of cytomegalovirus and toxoplasmosis in cases of miscarriages women in Al-Diwaniyah province. Al-Qadisiah Medical Journal. 2011;7(11):160 168.

40. Al-Muhanna ASJ, Al-Muhanna EK. Potential distribution of human cytomegalovirus in Al-Furat Al-Awset area of Iraq. Journal of Al-Qadisiyah for pure science. 2014;19(3):1-8.

41. Al-Khafaji AH, Al-Zubaidi KI. Seroprevalence of Cytomegolovirus Infection among aborted Women in Thi-Qar Governorate. Journal of Thi-Qar science. 2010;2(3):20-26.

42. Hadi NJ. Prevalence of Antibodies to Cytomegalovirus, Rubella Virus and Toxoplasma gondii among aborted women in Thiqar province. Journal of College of Education for Pure Science. 2011;1:3-9.

43. Al-Abady FAM, AL-GhezySJKh. Diagnostic study of Toxoplasma and Cytomegalovirus gondii in pregnant and aborted women in Thi-Qar governorate. Journal of College of Education for Pure Science. 2013;3(1):70-94. 
44. AL-Taie AAD. Serological Study For TORCH infections in women with high delivery risk factors In Mosul. Tikrit Journal of Pure Science. 2010;15(1):193-198.

45. Hama SA, Abdurahman KJ. Human Cytomegalovirus IgG and IgM Seropositivity among pregnant women in Sulaimani City and Their Relations to the Abortion Rates. Current Research Journal of Biological Sciences. 2013;5(4):161-167.

46. Hassan HMM, Alsamarai AM, Mohamed ZK, et al. Association between Cytomegalovirus infection and bad obstetric outcomes in women from Kirkuk. International Journal of Public Health Science. 2014;3(1):2942.

47. Mukhlis FA. Detection of Human Cytomegalovirus in Colorectal Adenocarcinoma by In Situ hybridization technique. Journal of the Faculty of Medicine. 2009;51:52-56.

48. Allawi AG, Samad ABA, Nazar AMA. Investigation of human Cytomegalovirus pp43 \& pp76 in colon adenocarcinoma Using Immunohistochemistry (IHC) technique. Al-Qadisiah Medical Journal. 2008;4(6):1-8.

49. Al-Obaidi AB. Human Cytomegalovirus and Colorectal Adenocarcinoma: any association? Iraqi journal of medical sciences. 2008;6(2):54-57.

50. AL-Mosawi J. Determination of human cytomegalovirus proteins in the paraffin-embedded tissues of colorectal Adenocarcinoma. Kufa medical journal. 2008;11(1):334-342.

51. Al-Mosawi J, Al-Obaidi I, Al-Shammary AMA. Detection of human cytomegalovirus Pp65 in colorectal adeno- carcinoma and villous adenoma using Immunohistochemistry (IHC) technique. Thi-Qar medical journal. 2007;1(1):55-64

52. AL-Mosawi J, Adwar L, AL-Shammary AMA. Study of Human Cytomegalovirus nucleic acid in specimens of colorectal adenocarcinoma and villous adenoma using Polymerase chain reaction (PCR) technique. $A L$ -Qadisiah Medical Journal. 2011;7(11):33-44.

53. Abdullah SF, Mukhlis FA, Abdul Majeed BA. Detection of human cytomegalovirus genome in malignant gliomas by in situ hybridization technique. Journal of the Faculty of Medicine. 2009;51(2):178-183.

54. Shamran HA, Kadhim HS, Hussain AR, et al. Detection of Human Cytomegalovirus in different histopathological types of Glioma in Iraqi Patients. Bio Med Research Int. 2015;2015:642652.

55. Ali SHM, Al Jewari MMM, Saaed NAAH. Localization of Human Cytomegalovirus- Late Gene DNA, Expression of P53 Gene and CD8-Tumor Infiltrating Lymphocytes in Oral Squamous Cell Carcinoma. Iraqi postgraduate Medical Journal. 2013;12(2):296-305.
56. Omer AR, Salih JI, Al-Nakshabandi AA. Frequency of blood-born viral infections among leukemic patients in central Iraq. Saudi Med J. 2011;32(1):55-61.

57. Mohammed AH, Kadhim HS, Ghani AH. Investigation the role of human cytomegalovirus in the invasive ductal breast carcinoma. Clinical cancer investigation journal. 2015;4(2):199-205.

58. Yasir SJ, Majhol RB, Khalil AM. Screening of anti-cytomegalovirus IgG antibodies in blood donors in Al-Najaf governorate. Kufa medical journal. 2008;11(2):271-276.

59. Al-Dabbagh KA. Detection of Toxoplasma gondii IgM and Cytomegalovirus IgM antibodies among blood donors in Mosul. Irq J Pharm. 2011;11(2):85-92.

60. Yasir SJ, Abbas HH, Al-Heidery ZH. Screening of Human Cytomegalovirus (CMV) in Diabetic Patients in Najaf Governorate. Medical journal of Babylon. 2013;10(1):236-244.

61. Yasir SJ, Mashkoor KT, Al-Mola GA. Detection of Human Cytomegalovirus (HCMV) among Infertile Male in AL-Najaf governorate. Kufa journal of nursing science. 2012;2(3):123-128.

62. Al-Alousi HW. Frequency of Salivary Human Cytomegalovirus in Iraqi Patients with Chronic Periodontitis. J Fac Med Baghdad. 2013;55(2):162-165

63. Abid Aun WA, Edan DS. Detection of HCMV DNA in Chronic Periodontitis Patients by Real time PCR and its relation with the severity of disease. Al-Mustansiriyah Journal for Pharmaceutical Sciences. 2014;14(2):136-144.

64. Al-Layla EAH. Serum Screening about Herpes Simplex Virus in Thalassemia Patients in Mosul/Iraq and it Relation to Cytomegalovirus(CMV) and Toxoplasma gondii. Kirkuk university journal for scientific studies. 2012;7:62-78

65. Al-Azzawi SI, Ibraheem MF, Mohammad RK. Etiology \& prognostic factors of fulminant hepatic failure in children (a hospital -based study). Iraqi postgraduate Medical Journal. 2013;12(1):26-31.

66. Khudir MK, Molan A. Seroprevalence of cytomegalovirus among healthy students at Diyala University, Diyala, Iraq. Journal of Pharmacy and Biological Sciences. 2014;9(1):59-61. 